mial infection.

For the optimal training of investigators under realistic conditions, the proportion should be equal to the prevalence, but, as can be seen in Figure 2, a large number of cases is necessary for good validation quality. That is why validation by case studies with a composition of half the patients with nosocomial infections and the other half with symptoms of infections but not nosocomially infected might be the most efficient approach.

There is a need to develop recommendations regarding the most favorable method of validation.

\section{REFERENCES}

1. Haley RW, Schaberg DR, McClish DK, Quade D, Crossley KB, Culver $\mathrm{DH}$, et al. The accuracy of retrospective chart review in measuring nosocomial infection rates. Am J Epidemiol 1980;111:516-533.

2. Glenister HM, Taylor LJ, Bartlett CLR, Cooke EM, Sedgwick JA, Mackintosh CA. An evaluation of surveillance methods for detecting infections in hospital inpatients. J Hosp Infect 1993;23:229-242.

3. Laxson L, Blaser M, Parkhurst S. Surveillance for the detection of nosocomial infections and the potential for nosocomial outbreaks, I: microbiology culture surveillance is an effective method of detecting nosocomial infection. Am J Infect Control 1984;12:318-324.

4. Lima NL, Pereira CRB, Souza IC, Facanha MC, Lima AAM, Guerrant $\mathrm{RL}$, et al. Selective surveillance for nosocomial infections in a Brazilian hospital. Infect Control Hosp Epidemiol 1993;14:197-202.

5. Wenzel RP, Osterman CA. Hunting KJ, Gwaltney, JM. Hospital-acquired infections, I: surveillance in a university hospital. Am J Epidemiol 1976;103:251-260.

6. Hirschhorn L, Currier J, Platt R. Electronic surveillance of antibiotic exposure and coded discharge diagnosis as indicator of postoperative infection and other quality assurance measures. Infect Control Hosp Epidemiol 1993;14:21-28.

7. Eickhoff T, Brachman P, Bennett J, Brown J. Surveillance of nosocomia infections in community hospitals, I: surveillance methods, effectiveness, and initial results. J Infect Dis 1969;12:305-317.

8. Hargreaves JE, Mann C, Hansen S. Validation of unit-based infection control instituted by staff nursing to identify nosocomial infections in the surgical patient. Infect Control Hosp Epidemiol 1995;16(suppl 2):27.

9. Wenzel RP, Osterman CA, Townsend TR, Veazey JM, Servis KH, Miller LS, et al. Development of a statewide program for surveillance and reporting of hospital-acquired infections. J Infect Dis 1979;140:741-746.

10. Broderick A, Motomi M, Nettleman MD, Streed SA, Wenzel RP. Nosocomial infections: validation of surveillance and computer modelling to identify patients at risk. Am J Epidemiol 1990;131:734-742.

11. Ehrenkranz NJ, Schulz JM, Richter EI. Recorded criteria as a 'gold standard' for sensitivity and specificity estimates of surveillance of nosocomial infection: a novel method to measure job performance. Infect Control Hosp Epidemiol 1995;16:697-702.

12. Gastmeier P, Kampf G, Wischnewski N, Hauer T, Schulgen G, Schumacher M, et al. Prevalence of nosocomial infections in representative German hospitals. J Hosp Infect 1998;38:37-49.

13. Garner JS, Jarvis WR, Emori TG, Horan TC, Hughes JM. CDC definitions for nosocomial infections, 1988. Am J Infect Control 1988;16:128140.

14. Larson E, Horan T, Cooper B, Kotilainen HR, Landry S, Terry B. Study of the definition of nosocomial infections. Am J Infect Control 1991;19:259-267.

15. McCullagh P, Nelder JA. Generalized Linear Models. Cambridge, MA: University Press; 1989.

16. Cardo DM, Falk PS, Mayhall CG. Validation of surgical wound surveillance. Infect Control Hosp Epidemiol 1993;14:211-215.

17. Emori TG, Edwards JR, Culver DH, Sartor C, Stroud LM, Gaunt EE, et al. Accuracy of reporting nosocomial infections in intensive-care unit patients to the National Nosocomial Infections Surveillance System: a pilot study. Infect Control Hosp Epidemiol 1998;19:308-316.

18. Freeman J, McGowan JE. Methodologic issues in hospital epidemiology, I: rates, case-finding, and interpretation. Rev Infect Dis 1981;3:658-667.

19. Tablan OC, Anderson LJ, Arden NH, Breiman RF, Butler JC, McNeil MM, the Hospital Infection Control Practices Advisory Committee. Guideline for the prevention of nosocomial pneumonia. Infect Control Hosp Epidemiol 1994;15:587-627.

20. A'Court C, Garrard CS. Nosocomial pneumonia in the intensive care unit: mechanisms and significance. Thorax 1992;47:465-473.

21. Fagon JY, Hance AJ, Montraves P, Novara A, Gilbert C. Nosocomial pneumonia in ventilated patients: a cohort study evaluating attributable mortality and hospital stay. Am J Med 1993;94:281-288.

22. Meduri, GU. Ventilator-associated pneumonia in patients with respiratory failure. Chest 1990;97:1208-1219.

23. Hospitals in Europe Link for Infection Control Through Surveillance. HELICS protocol for nosocomial infection surveillance in intensive care units. Brussels, Utrecht, Copenhagen, Lyon; 1995.

24. Horan TC, Emori TG, Stroud LA, Edwards JR, Culver DH, Gaynes RP. CDC definitions of nosocomial infections (NI): clarifications and revisions based on the National Nosocomial Surveillance (NNIS) system evaluation study. Infect Control Hosp Epidemiol 1997;18(suppl 2):49.

\title{
HIV Incidence Among Teens and Young Adults
}

\section{Gina Pugliese, RN, MS Martin S. Favero, PhD}

Behaviors that result in potential exposure to human immunodeficiency virus (HIV) usually begin in adolescence or young adulthood, but trends in HIV incidence in young people remain unclear. Researchers from Bethesda, Maryland, estimated the trends in HIV incidence in teenagers and young adults with back-calculations HIV incidence in persons born between 1960 and 1974 using US national acquired immunodeficiency syndrome (AIDS) incidence data and estimates of the distribution of times between HIV infection and AIDS.

As of January 1993, approximately
22,000 men and 11,000 women aged 18 to 22 years were living with HIV infection in the United States. Homosexual contact was the leading route of infection among young men. Heterosexual contact was the leading route of infection among young women. The HIV incidence attributed to homosexual contact or injection drug use decreased among persons aged 20 and 25 years between 1988 and 1993 , but HIV incidence attributed to heterosexual contact was stable or increasing. Notably, in men aged 20 and 25 years, HIV prevalence declined by approximately $50 \%$ in white men but was relatively stable in black and Hispanic men. In contrast, HIV prevalence in women aged 20 and 25 years rose by $36 \%$ and
$45 \%$, respectively, because of increasing heterosexual transmission. Overall, HIV prevalence in persons aged 20 and 25 years declined by only $14 \%$ between 1988 and 1993.

The researchers concluded that, in young persons, HIV incidence in homosexual men and injection drug users was slowing by 1993; this favorable trend was offset by increasing heterosexual transmission, especially in minorities.

FROM: Rosenberg PS, Biggar RJ. Trends in HIV incidence among young adults in the United States. JAMA 1998;279:1894-1899. 